\title{
PENGEMBANGAN TES DIAGNOSTIK KESULITAN BELAJAR MATEMATIKA DI SD
}

\author{
${ }^{1)}$ M. Duskri, ${ }^{2)}$ Kumaidi, ${ }^{3)}$ Suryanto \\ ${ }^{1)}$ UIN Ar-Raniry Banda Aceh, ${ }^{2)}$ Universitas Muhammadiyah Surakarta, \\ ${ }^{3}$ Universitas Negeri Yogyakarta \\ 1)duskri_iainaceh@yahoo.co.id, ${ }^{2}$ kuma426@yahoo.com.
}

\begin{abstract}
Abstrak
Tujuan penelitian untuk: (1) menemukan prosedur pengembangan tes diagnostik kesulitan belajar matematika SD/MI, (2) mengetahui kualitas butir tes diagnostik yang dikembangkan, dan (3) mengetahui informasi yang dapat dimunculkan dari hasil analisis tes diagnostik. Penelitian ini merupakan penelitian pengembangan dari Borg \& Gall. Subjek uji sebanyak 542 orang siswa kelas VI SD/MI di Kota Banda Aceh dan Aceh Besar. Analisis kuantitatif untuk mengetahui informasi butir tes menggunakan program ITEMAN dan Program R. Hasil penelitian menunjukkan: (1) pengembangan tes diagnostik kesulitan belajar matematika di SD ini meliputi: studi pendahuluan, studi literatur dan hasil-hasil penelitian, analisis masalah, merumuskan learning continuum, merumuskan peta konsep, menyusun tes essay, polarisasi jawaban siswa, menyusun tes bentuk pilihan ganda, validasi pakar melalui focus group discussion, uji coba terbatas, dan uji yang diperluas, (2) indeks daya beda butir tes antara 0,391 sampai dengan 2,317, indeks kesukaran butir tes antara $-2,158$ sampai dengan 2,528, kecocokan uji tes dengan kemampuan peserta $(\theta)$ antara $-2,00$ sampai dengan 2,60, dan fungsi informasi tes antara 0,111 sampai dengan 3,879, dan (3) informasi yang dapat dimunculkan dari tes meliputi: hasil tes secara klasikal dan individual, grafik ketuntasan belajar, profil individual, analisis salah konsepsi dan saran remedial.
\end{abstract}

Kata kunci: tes diagnostik, kesulitan belajar matematika

\section{DEVELOPING DIAGNOSTIC TEST OF MATHEMATICS LEARNING DIFFICULTIES IN ELEMENTARY SCHOOLS}

\author{
${ }^{1)}$ M. Duskri, ${ }^{2)}$ Kumaidi, ${ }^{3)}$ Suryanto \\ ${ }^{1)}$ UIN Ar-Raniry Banda Aceh, ${ }^{2)}$ Universitas Muhammadiyah Surakarta, \\ ${ }^{3)}$ Universitas Negeri Yogyakarta \\ 1)duskri_iainaceh@yahoo.co.id, ${ }^{2}$ kuma426@yahoo.com.
}

\begin{abstract}
The purposes of this study were: (1)to find a method to develop diagnostic test of mathematics learning difficulties in primary schools, (2) to determine the diagnostic test characteristics developed, and (3) to determine the information that could be generated by using diagnostic test. This study was a development research by Borg \& Gall. The participants of main field testing were 542 grade VI students of primary schools in Banda Aceh City and Aceh Besar Regency. The quantitative analysis to determine the information of the test items developed used ITEMAN program and R Program. The results of this study are: (1) in developing the diagnostic test of the mathematics learning difficulties, the research phase included preliminary study, literature and research results study, problem analysis, formulating learning continuum, formulating concept map, preparing essay-form tests, students' answers polarization, preparing multiple-choice tests, experts' validation with focus group discussion, preliminary and readability tests, operational field testing, and main field testing to obtain model that fitted theoretically and empirically, (2) discriminating power of test items index ranges from 0.391 to 2.317 , the difficulty test items index ranges from -2.158 to 2.528 , the test compatibility testing with the participants ability (0) ranges from -2.00 to 2.60 and the test information function ranges from 0.111 to 3.879 , and (3) the information that can be generated from the diagnostic test includes classically and individually test results, graphic of learning outcomes attainment, individual profile, every answers analysis, false conception and remedial suggestion analysis.
\end{abstract}

Keywords: diagnostic test, mathematics learning difficulties 


\section{Pendahuluan}

Salah satu ciri dari mata pelajaran matematika adalah bertumpu pada pengetahuan atau pengalaman sebelumnya, deduktif dan abstrak. Belajar matematika pada hakikatnya belajar tentang konsep, struktur konsep dan mencari hubungan antarkonsep dan strukturnya (Subarinah, 2006, p.1). Oleh sebab itu, jika terjadi miskonsepsi pada konsep sebelumnya, maka dapat dipastikan akan berakibat miskonsepsi pula pada konsep berikutnya. Apabila miskonsepsi ini tidak dibenahi, maka peserta didik akan mengalami kesulitan dalam belajar matematika. Bagi peserta didik, kesulitan dalam mempelajari matematika akan berakibat keputusasaan, tidak berminat dan pada akhirnya akan membenci pelajaran matematika.

Berdasarkan hasil survei dari Programme for International Student Assessment (PISA) bahwa kemampuan matematika anak-anak Indonesia dalam usia kisaran 15 tahun di dunia internasional berada pada peringkat yang belum memuaskan. Sebagaimana dirilis dalam laman Litbang Kemendikbud, bahwa Indonesia selalu berada di bawah skor ratarata internasional yaitu 500. Pada tahun 2000, Indonesia menduduki peringkat 39 dari 41 negara dengan skor rata-rata 367, tahun 2003 menduduki peringkat 38 dari 40 negara dengan skor rata-rata 361 , tahun 2006 menduduki peringkat 50 dari 57 negara dengan skor rata-rata 391, dan tahun 2009 menduduki peringkat 61 dari 65 negara dengan skor rata-rata 371 (Litbang Kemendikbud, 2011). Hasil PISA matematika tahun 2009, ternyata 43,5\% siswa Indonesia tidak mampu menyelesaikan soal PISA paling sederhana, $33,1 \%$ hanya mampu mengerjakan soal jika pertanyaan dari soal kontekstual diberikan secara eksplisit serta semua data yang dibutuhkan untuk mengerjakan soal diberikan secara tepat, dan hanya $0,1 \%$ siswa Indonesia yang mampu mengembangkan dan mengerjakan pemodelan matematika yang menuntut keterampilan berpikir dan penalaran (Wijaya, 2012, p.2). Hasil-hasil tersebut menunjukkan bahwa kemampuan pemecahan masalah bagi sebagian besar siswa Indonesia masih rendah, hal ini perlu menjadi perhatian guru-guru dalam melakukan pembelajaran matematika tidak hanya berlatih mengerjakan soal yang secara eksplisit telah tersedia semua argumen yang dibutuhkan, akan tetapi lebih dari itu, yaitu membelajarkan siswa agar mampu berfikir kritis. Dengan demikian, siswa akan mampu menyelesaikan persoalan-persoalan matematika yang menuntut pemikiran dan penalaran.

Trends in International Mathematics and Science Study (TIMSS) pada tahun 1999, 2003 dan 2007 melakukan studi internasional tentang prestasi matematika dan sains siswa sekolah lanjutan tingkat pertama. Bidang matematika yang diuji dalam studi tersebut adalah kemampuan dalam materi bilangan, aljabar, geometri, data dan peluang. Berdasarkan hasil survei tersebut, ternyata kemampuan rata-rata siswa-siswi Indonesia masih di bawah rata-rata internasional. Khusus untuk bidang matematika, pada tahun 1999 skor rata-rata internasional 487, sedangkan Indonesia mendapat skor ratarata 403 dan menduduki peringkat 34 dari 38 negara yang disurvei. Pada tahun 2003 skor rata-rata internasional 467, sedangkan Indonesia mendapat skor rata-rata 411 dan menduduki peringkat 35 dari 46 negara yang disurvei. Pada tahun 2007 skor ratarata internasional 500, sedangkan Indonesia mendapat skor rata-rata 397 dan menduduki peringkat 36 dari 49 negara yang disurvei (Litbang Kemdikbud, 2011).

Sejalan dengan pernyataan di atas, berdasarkan hasil laporan dari penelitian yang dilakukan oleh Tim Pusat Pengembangan Penataran Guru Matematika yang meneliti pada beberapa Sekolah Dasar di Indonesia mengungkapkan bahwa 51\% siswa kesulitan dalam aspek berhitung, 50\% siswa kesulitan dalam penguasaan konsep, dan 49\% siswa mengalami kesulitan dalam menyelesaikan soal cerita (Tim PPPG Matematika, 2001, p.18). Selanjutnya, pada tahun 2002 berdasarkan hasil penelitian dari Tim PPPG Matematika mengungkapkan bahwa di beberapa wilayah Indonesia, sebagian besar siswa SD kesulitan dalam menyelesaikan soal-soal cerita dan menerjemahkan soal cerita ke da- 
lam model matematika (Tim PPPG Matematika, 2002, p.71).

Rendahnya mutu pendidikan, termasuk hasil pembelajaran yang dicapai sebagaimana yang telah disebutkan di atas (termasuk pembelajaran matematika) dapat disebabkan oleh berbagai faktor, antara lain karakteristik mata pelajaran, siswa dan guru. Matematika dibangun atas konsep-konsep yang abstrak dan deduktif, akibatnya sukar dipahami oleh sebagian besar siswa.

Soedjadi (1996, p.2) menyatakan bahwa siswa SLTP lemah dalam penguasaan geometri, pecahan, dan soal cerita. Lemahnya penguasaan siswa pada jenjang SMP ini boleh jadi disebabkan oleh lemahnya penguasaan siswa terhadap matematika ketika berada pada jenjang SD/MI. Penyebab lain karena matematika menggunakan simbolsimbol, berfikir deduktif, dan abstrak. Bagi siswa yang masih mengalami kendala pada materi tertentu, perlu diberikan bimbingan tersendiri, misalnya dalam bentuk remedial teaching. Menurut Ischak \& Warji (1992, p.35) rendahnya hasil belajar matematika dimungkinkan penyebabnya karena tidak efektif (maksimal) pemberian bantuan belajar berupa remedial teaching kepada siswa yang mengalami kesulitan.

Proses pembelajaran dapat berjalan efektif dan sukses apabila perbedaan-perbedaan individu (individual differences) yang ada di antara peserta didik mendapat perhatian (Suwarsono, 1987, p.69) dan dapat dideteksi. Perbedaan-perbedaan tersebut akan berpengaruh terhadap tingkat pemahaman siswa dalam mempelajari materi tertentu. Diketahuinya perbedaan-perbedaan individual (terutama kesulitan dalam memahami materi pelajaran), faktor yang ikut menjadi penyebab kesulitan, dan faktor utama penyebab kesulitan tersebut, maka kegiatan pembelajaran yang akan dilakukan oleh guru dapat disesuaikan. Untuk mengetahui perbedaan tingkat pemahaman peserta didik (terutama kesulitan dalam memahami materi pelajaran), faktor yang ikut menjadi penyebab kesulitan, dan faktor utama penyebab kesulitan tersebut dapat dilakukan dengan tes diagnostik kesulitan belajar.
Diagnosis dalam pendidikan merupakan konsep yang luas, meliputi identifikasi kekuatan dan kelemahan peserta didik (Sriati, 1993; Thorndike dan Hagen, 1977, p.72). Sheehan (1997, p.333) menyatakan bahwa hasil tes bukan hanya menunjukkan berapa skor yang benar dan salah dari setiap siswa, namun memberikan informasi pola pencapaian ketuntasan kemampuan siswa. Informasi tersebut dapat membantu siswa dan guru untuk memahami lebih baik makna dari skor itu sendiri dalam kaitannya dengan peningkatan hasil belajar. Prosedur untuk menterjemahkan hasil tes dalam kaitannya dengan proses pembelajaran dapat dirancang melalui student-level diagnositic atau group-level diagnostic. Diagnosis level siswa secara individual menggambarkan kekuatan dan kelemahan tiap individual siswa masingmasing. Sedangkan diagnosis secara kelompok menggambarkan kekuatan dan kelemahan siswa yang didasarkan pada titik-titik tertentu berdasarkan laporan skala skor dari tes itu.

Waskito \& Kumaidi (2010) mengembangkan model analisis prestasi belajar untuk mengidentifikasi kesulitan belajar peserta didik dengan menyusun butir tes objektif pilihan ganda dan esai serta mengembangkan perangkat lunak (software) komputer yang dapat mengolah data dan laporan hasil tes diperoleh lebih cepat. Hasil analisisnya berupa: (1) profil diri individual peserta didik yang menggambarkan tentang penguasaan peserta didik terhadap kompetensi dasar yang telah dipelajari serta saran pembelajaran yang harus dilakukan untuk mengatasi kesulitan tersebut; (2) profil kelas yang memberikan informasi tentang siapa saja di kelas tersebut yang belum menguasai indikator soal; dan (3) grafik yang menggambarkan penguasaan setiap siswa terhadap materi pelajaran yang dites.

Penelitian yang dilakukan oleh Fauzan (2010) mendeskripsikan kesulitan-kesulitan yang dialami peserta didik terhadap materi ajar sesuai dengan indikator yang telah dirumuskan. Penelitian yang dilakukan oleh Waskito \& Kumaidi (2010) memberikan informasi tentang skor dan nilai tiap peserta 
didik dan memberikan saran apa saja yang harus dipelajari untuk mengatasi kesulitan tiap butir tes, serta memberikan informasi prestasi setiap siswa dibandingkan dengan ternan sekelasnya.

Berdasarkan hal tersebut, peneliti menggabungkan kedua hasil penelitian dari Fauzan (2010) dan Waskito \& Kumaidi (2010), dan melengkapinya dengan beberapa informasi penting lainnya. Hasil penelitian ini diharapkan mampu memberikan informasi tentang grafik kedudukan siswa di kelasnya dibandingkan dengan nilai Kriteria Ketuntasan Minimal (KKM) yang ditetapkan serta skor dan nilai yang diperolehnya, profil individual, deskripsi tentang konsepkonsep apa saja yang sudah dipahami, konsep-konsep apa saja yang belum dipahami, disertai dengan informasi dugaan kuat penyebab peserta didik mengalami kesulitan khususnya penguasaan materi prasyarat pada setiap konsep tersebut, dan memberikan saran materi pembelajaran apa saja yang harus diremedialkan terlebih dahulu untuk mengatasi kesulitan tersebut. Secara teoretis ini mungkin dilakukan, karena berdasarkan learning continum atau melalui tela'ah materi prasyarat akan dapat diprediksikan secara tepat penyebab kesulitan yang dialami siswa dan alternatif pemecahannya. Hal ini sangat membantu guru dalam merencanakan dan melaksanakan remedial teaching terhadap materi yang belum dikuasai oleh siswa.

Permasalahan dibatasi pada pengembangan tes diagnostik kesulitan belajar matematika di SD. Tes bentuk piliban ganda, tes uraian, dan wawancara telah banyak digunakan untuk mengungkap kesulitan belajar yang dialami siswa terhadap materi pelajaran matematika. Khusus untuk tes pilihan ganda, option tiap butimya masih jarang didasarkan pada polarisasi jawaban siswa terhadap butir tes tersebut dalam bentuk essay. Apabila hal itu dilakukan, akan dapat difungsikan sebagai alat untuk mendeteksi penyebab siswa tidak mampu menjawab butir tes tersebut dengan benar.

Tes diagnostik yang dikembangkan ini khusus untuk tes diagnostik kesulitan belajar matematika jenjang SD/MI pada kelas
VI. Dipilih kelas VI dengan asumsi bahwa mereka telah mempelajari pelajaran matematika selama beberapa tahun di bangku $\mathrm{SD} / \mathrm{MI}$, dengan harapan cakupan materi tes yang dikembangkan dapat menjangkau mulai dari kelas-kelas sebelumnya sampai dengan kelas VI SD/MI terutama untuk memprediksi kemungkinan kesalahan-kesalahan konsep yang mungkin telah dialami oleh peserta didik selama beberapa tahun.

Tujuan dari penelitian ini adalah untuk: (1) menemukan prosedur pengembangan tes diagnostik kesulitan belajar matematika SD/MI, (2) mengetahui kualitas butir tes diagnostik kesulitan belajar matematika SD/MI yang dikembangkan, dan (3) mengetahui informasi yang dapat dimunculkan dari hasil analisis tes diagnostik kesulitan belajar matematika SD/MI yang dikembangkan.

\section{Metode Penelitian}

Penelitian ini merupakan penelitian pengembangan (research and development), yakni pengembangan tes diagnostik kesulitan belajar matematika di SD. Produk yang akan dihasilkan dari penelitian ini adalah instrumen tes diagnostik kesulitan belajar matematika SD dan desain perangkat lunak program komputer untuk analisis hasil diagnostiknya.

Produk dari pengembangan tes diagnostik kesulitan belajar matematika di SD ini berupa instrumen tes diagnostik kesulitan belajar matematika SD/MI berbentuk pilihan ganda khusus materi bilangan. Setiap butir tes yang dikembangkan, option-option yang dihasilkan didasarkan pada polarisasi jawaban peserta yang diperoleh dari uji tes awal berbentuk essay. Kemungkinan option ini didapat dari hasil uji desain tes essay (dalam studi pendahuluan untuk kebutuhan need assessment) yang dilakukan di lapangan. Berdasarkan studi pendahuluan ini, didesain butir tes-butir tes diagnostik kesulitan belajar matematika SD/MI berbentuk pilihan ganda, dilanjutkan dengan focus group discussion (FGD), diujicobakan secara terbatas, dilakukan analisis kuantitatif dengan program iteman dan analisis kualitatif melalui FGD. Selanjutnya, dikembangkan lagi menjadi bu- 
tir tes-butir tes yang akan digunakan untuk uji tes yang diperluas, dilakukan analisis kuantitatif dengan program Iteman, program $\mathrm{R}$ dengan 1 parameter dan 2 parameter, analisis kualitatif melalui FGD sampai kepada tahap revisi produk akhir.

Kriteria-kriteria peserta yang dilibatkan dalam FGD di antaranya paling tidak: (1) menguasai materi matematika SD/MI, (2) minimal telah mengajar mata pelajaran/ bidang studi matematika selama 5 tahun, (3) guru bidang studi matematika yang terlibat sebagai instruktur atau narasumber pada kegiatan KKG/PKG, dan (4) dosen pada Prodi Pendidikan Matematika/PGSD/PGMI minimal berpendidikan S-2 Pendidikan Dasar/Pendidikan Matematika dan telah berpengalaman mengajar minimal 3 tahun di PGSD/PGMI.

Kualitas dari produk instrumen tes diagnostik kesulitan belajar matematika SD/ MI diteliti berdasarkan: (1) penilaian para ahli melalui expert judgment dengan menggunakan teknik focus group discussion (FGD); (2) analisis menggunakan teori tes klasik (program ITEMAN), item response theory (IRT) dengan satu dan dua parameter (program R); dan (3) uji lapangan. Sedangkan untuk menguji kualitas produk berupa desain program komputer untuk analisis hasil diagnostiknya diteliti berdasarkan: (1) uji coba produk dengan melibatkan sejumlah guru dan fasilitator dalam pembelajaran; dan (2) verifikasi hasil uji coba.

Subjek coba penelitian ini sebanyak 542 siswa kelas VI SD/MI di Kota Banda Aceh dan Aceh Besar Provinsi Aceh. Diambil siswa kelas VI dengan pertimbangan bahwa mereka telah mempelajari sejumlah materi mulai dari kelas I sampai dengan kelas VI.

Data empirik merupakan data primer yaitu data yang diperoleh dari sumber primer yaitu respons siswa terhadap butir tes, para guru, dan expert dalam bidang pendidikan matematika, dan pakar evaluasi pendidikan yang tergabung dalam Focus Group Discussion. Data yang diperoleh dianalisis, dan digunakan untuk pengambilan keputusan dalam penelitian pengembangan ini.
Data kualitatif berupa masukan dari para ahli yang menjadi peserta Focus Group Discussion, yaitu ahli pendidikan matematika (dosen pendidikan matematika, guru yang mengajar matematika), dan ahli pengukuran dan evaluasi (dosen pengukuran atau evaluasi pendidikan), serta reviewer dari dosen Prodi PGMI/Pendidikan Matematika, mahasiswa Program Pascasarjana Prodi Pendidikan Matematika, dan guru yang mengajar matematika.

Masukannya berupa kebenaran konsep matematika yang diujikan dalam instrumen (butir tes), kesesuaian indikator kemampuan dengan Kompetensi Dasar, kesesuaian butir soal-butir soal dengan materi yang terkandung dalam kurikulum yang didasarkan pada Kompetensi Dasar, kesesuaian peta konsep yang dibuat untuk mendapatkan informasi materi pra-syarat yang sesuai dengan materi pokok, konstruksi tes, bahasa yang digunakan (menggunakan bahasa Indonesia yang benar dan dapat dimengerti oleh usia anak sekolah dasar), ketepatan instrumen untuk mendiagnosis kesulitan belajar matematika siswa sekolah dasar khususnya berkenaan dengan materi bilangan, kesesuaian rumusan pilihan alternatif jawaban tiap butir dengan dugaan terjadinya penyebab salah konsepsi (penyebab siswa mengalami kesulitan dalam menjawab butir soal), dan kesesuaian saran remedial pembelajaran yang diajukan untuk mengatasi salah konsepsi. Kejelasan petunjuk soal, kecukupan alokasi waktu yang tersedia untuk menyelesaikan soal, dan kelengkapan perangkat yang harus disediakan untuk mendiagnosis kesulitan belajar matematika juga perlu mendapatkan masukan.

Data kualitatif lainnya berupa penilaian tim validator terhadap perangkat tes diagnostik secara keseluruhan baik sebelum uji coba maupun setelah direvisi yang didasarkan pada uji coba lapangan. Data ini diperlukan untuk mendapatkan informasi tentang reliabilitas antar validator terhadap validasi instrumen tes yang mereka lakukan.

Data kuantitatif berupa skor peserta didik setelah merespons tes diagnostik multiple choice dalam uji coba terbatas dan uji 
yang diperluas. Data tersebut digunakan untuk validasi empiris terhadap kualitas butir tes berupa tingkat kesulitan soal, daya beda soal, keberfungsian pengecoh tiap butir tes, dan reliabilitas instrumen tes secara keseluruban. Khusus untuk data empiris setelah uji yang diperluas, di samping informasi tersebut juga diperlukan informasi berupa estimasi kemampuan peserta, estimasi daya beda soal tiap butir, estimasi tingkat kesulitan tiap butir tes, dan fungsi informasi tes.

Instrumen pengumpulan data terdiri atas: (1) tes diagnostik kesulitan belajar matematika SD berbentuk essay bertujuan need assessment untuk mendapatkan kondisi riel yang dialami oleh siswa, dari sini akan didapatkan polarisasi jawaban siswa, digunakan untuk merancang option tiap butir tes, (2) lembar validasi soal, (3) tes diagnostik kesulitan belajar matematika SD berbentuk pilihan ganda yang bertujuan untuk mengetahui kecocokan model, dan (4) rubrik penilaian secara kualitatif yang terdiri atas soal, kunci jawaban, analisis pengecoh (distractor), penyebab salah konsepsi, dan saran remedi pembelajaran. Data masukan dari para ahli melalui expert judgment terhadap produk awal (produk ke I) tes diagnostik kesulitan belajar matematika di SD (TDKB-MatSD) yang dikembangkan dianalisis secara deskriptif dengan memverifikasi masukan tersebut, dijadikan sebagai bahan untuk merevisi produk awal TDKB-MatSD.

Produk awal (produk ke I berupa tes essay) dilakukan uji pendahuluan untuk mendapatkan polarisasi jawaban peserta yang berguna untuk merancang option tiap butir tes. Berdasarkan hasil analisis uji pendahuluan dikembangkan lagi menjadi produk ke II berupa butir tes-butir tes pilihan ganda. Produk ke II ini dinilai oleh beberapa orang dosen Prodi PGMI/Pendidikan Matematika, dan didiskusikan lagi dengan tim reviewer untuk mendapatkan masukan perbaikan. Diskusi ini difokuskan pada kesesuaian rumusan indikator kemampuan dengan Kompetensi Dasar, butir tes yang dirumuskan, konstruk tes yang telah dirumuskan, option tiap butir tes, kebahasaan, analisis pengecoh (distractor). Masukan dari reviewer dan hasil penilaian oleh beberapa orang dosen tersebut digunakan untuk memperbaiki produk ke II (TDKB-MatSD).

Setelah diperoleh butir tes-butir tes yang telah sesuai dengan kriteria (valid dan reliabel secara empiris) yang dianalisis melalui teori tes klasik (ITEMAN) yang menghasilkan produk III TDKB-MatSD, selanjutnya dilakukan uji yang diperluas untuk mendapatkan informasi keterlaksanaan di lapangan. Subjek penelitian untuk uji yang diperluas sebanyak 542 orang siswa kelas VI yang tersebar di 10 SD/MI Kota Banda Aceh dan Aceh Besar.

Data kuantitatif hasil uji yang diperluas dianalisis dengan teori respons butir model logistik 1 parameter dan 2 parameter melalui program R. Sebelum menggunakan analisis teori respons butir, terlebih dahulu dilakukan pemeriksaan asumsi unidimensional dan independen lokal (Hambleton, et. al., 1991). Asumsi pertama, unidimensional menyatakan bahwa dalam setiap tes hanya ada satu kemampuan yang diukur oleh perangkat butir-butirnya. Asumsi ini sangat sulit dipenuhi karena begitu banyaknya faktor yang mempengaruhi tes, seperti kognitif, kepribadian, motivasi, kecemasan, dan lain sebagainya. Namun demikian, yang paling penting adalah adanya satu komponen yang paling dominan dalam menentukan kemampuan subjek. Salah satu cara pemeriksaan unidimensi adalah dengan melakukan faktor analisis yang menghasilkan eigenvalue. Apabila eigenvalue salah satu faktor mempunyai nilai lebih dominan dan beberapa kali dibandingkan dengan eigenvalue faktor yang lainnya, maka dapat dikatakan syarat unidimensi sudah terpenuhi (Naga, 1992, p.297). Penelitian ini menggunakan analisis program $\mathrm{R}$ untuk menentukan matrix of tertachoric correlations antar-item dan dianggap memenuhi persyaratan apabila eigenvalue $>1$.

Asumsi kedua, local independence (independensi lokal) yaitu respons peserta tes terhadap suatu butir tidak berhubungan dengan butir lainnya dalam tes tersebut. Independensi lokal dimaksudkan sebagai 
letak pada suatu titik di kontinum parameter ciri peserta tes yakni $\theta$ (Naga, 1992, p.170). Hal ini dapat diamati dari fungsi informasi butir tes dan fungsi respons butir tes. Selain dua asumsi di atas, asumsi yang juga harus dipenuhi adalah invariansi parameter. Asumsi ini menyatakan bahwa parameter butir tidak tergantung pada parameter siswa dan sebaliknya parameter siswa tidak tergantung parameter butir. Invariansi pada butir tes dibedakan dalam dua bagian, yaitu: (1) invariansi terhadap estimasi parameterparameter butir tes, dan (2) invariansi terhadap parameter kemampuan (Hambleton, Swaminathan, \& Rogers, 1991, p.19).

Memeriksa invariansi terhadap estimasi kemampuan, butir tes dipilah menjadi kelompok butir tes ganjil dan butir tes genap, dilakukan estimasi dengan program $\mathrm{R}$ sehingga diperoleh parameter kemampuan setiap siswa dari kedua kelompok. Kedua kelompok kemampuan dikorelasikan, apabila korelasinya tinggi, maka asumsi invariansi kemampuan terpenuhi (Syarifah, 2007, p.16). Korelasi estimasi parameter kemampuan peserta kelompok item ganjil dan item genap dilakukan dengan program SPSS versi 17.

Analisis melalui teori respons butir bertujuan untuk mendapatkan estimasi daya beda butir tes, estimasi tingkat kesukaran butir tes, estimasi kemampuan peserta, grafik fungsi informasi butir tes, dan grafik fungsi respons butir tes. Dali S. Naga (1992, pp.223-224) menyatakan bahwa batas nilai parameter kemampuan peserta yang berguna secara praktis terletak antara $-4 \leq \theta$ $\leq+4$, parameter daya pembeda butir tes harus bernilai positif $\left(a_{i}>0\right)$, parameter tingkat kesukaran butir tes membentang sepanjang nilai $\theta$ (idealnya $-2 \leq \mathrm{b}_{\mathrm{j}} \leq+2$ ), dan nilai guessing (tebakan) $0 \leq \mathrm{c}_{\mathrm{i}} \leq 1$, idealnya nilai $c_{j}$ terletak disekitar 0,25. Berhubung subjek penelitian ini berjumlah 542 orang maka peneliti hanya menganalisis dengan model logistik 1 parameter dan 2 parameter, sehingga nilai tebakan dianggap 0 . Estimasi karakteristik butir, estimasi kemampuan peserta, dan uji fit tidaknya butir tes terhadap model, yaitu baik model logistik 1 para- meter maupun model logistik 2 parameter dilakukan dengan program R. Setelah dilakukan uji fit butir tes terhadap model, maka kedua model dibandingkan, yang paling banyak butir tesnya fit, model tersebutlah yang paling cocok. Uji kecocokan tiap butir tes dengan model dilakukan dengan membandingkan nilai $\chi^{2}$ hitung dan nilai $\chi^{2}$ tabel. Apabila $\chi^{2}$ hitung $<$ nilai $\chi^{2}$ tabel dengan taraf signifikansi 0,05 atau nilai peluang yang dihasilkan (uji fit model melalui program R) lebih besar dari 0,05 maka butir tes tersebut cocok dengan model, namun apabila sebaliknya maka butir tersebut tidak cocok dengan model.

Uji kelayakan penggunaan software komputer TDKB-MatSD diuji coba langsung oleh 15 orang guru SD/MI di laboratorium komputer Prodi Pendidikan Matematika Fakultas Tarbiyah IAIN Ar-Raniry pada tanggal 2 Mei 2013. Guru diminta membaca hasil print out analisis komputer yang terdiri atas: (1) profil siswa secara individual berupa: skor, nilai yang diperoleh, ketuntasan individual, deskripsi indikator (materi) yang telah dikuasai, deskripsi indikator (materi) yang belum dikusasi, deskripsi dugaan penyebab siswa mengalami kesulitan terhadap materi tersebut, dan deskripsi saran remedial yang ditawarkan untuk mengatasi kesulitan tersebut, dan (2) profil secara klasikal berupa: ketuntasan secara klasikal dan individual, grafik ketuntasan secara individual dan klasikal, dan ketuntasan indikator (materi) yang diujikan. Hasil uji coba software dan print out analisisnya, guru diminta memberikan masukan dan penilaian terhadap produk-produk tersebut melalui instrumen uji validasi software komputer yang diberikan kepada tiap guru. Data tersebut berupa tanggapan terhadap tiap butir pernyataan: sangat setuju (4), setuju (3), kurang setuju (2), dan tidak setuju (1). Hasil tanggapan guru tersebut dihitung nilai rata-rata tiap butir pernyataan, dengan kriteria: ratarata 1-1,50 berarti jelek; rata-rata 1,51-2,50 berarti cukup, rata-rata 2,51-3,50 berarti baik, dan rata-rata 3,51-4 berarti baik sekali.

Uji kelayakan dan efektivitas TDKBMatSD dalam mendiagnosis kesulitan siswa 
terhadap indikator yang diujikan, dilakukan dengan teknik uji beda antara dua rerata (Borg \& Gall, 1983, pp.543-545). Rerata skor siswa yang berasal dari sekolah favorit dan rerata skor siswa yang berasal dari sekolah nonfavorit dibandingkan. TDK.BMatSD dianggap efektif dalam mendiagnosis kesulitan belajar siswa, apabila diperoleh perbedaan yang signifikan antara hasil tes siswa yang berasal dari sekolah yang favorit dan sekolah nonfavorit. Pengujian ini dilakukan dengan program SPSS versi 17.0, apabila nilai signifikansinya $<0,05$ berati TDKB-MatSD yang telah dikembangkan dianggap efektif untuk mendiagnosis kesulitan belajar siswa.

\section{Hasil Penelitian dan Pembahasan}

Secara keseluruhan butir tes yang dikembang memenuhi asumsi-asumsi yang men-dasari analisis dengan teori respon butir. Asumsi pertama, unidimensi terpenuhi, karena uji unidimensi dengan menggunakan program $\mathrm{R}$ diperoleh eigenvalue data sebesar 2,4025 dan nilai signifikasni hasil perhitungan sebesar 0,0099 lebih kecil dari signifikasi yang dipilih 0,05 . Hasil uji unidimensi ini juga menunjukkan bahwa butir yang dikembangkan hanya satu faktor, yang berarti validitas konstruknya juga terpenuhi.

Asumsi kedua, local independence (independensi lokal) yaitu respons peserta tes terhadap suatu butir tidak berhubungan dengan butir lainnya dalam tes tersebut. Independensi lokal dimaksudkan sebagai letak pada suatu titik di kontinum parameter ciri peserta tes yakni $\theta$ (Hambleton, Swaminathan, \& Rogers, 1991, p.10). Hal ini dapat diamati dari fungsi informasi butir tes dan fungsi respons butir tes. Hampir semua butir tes memenuhi fungsi informasi yang ideal dan fungsi respons butir yang mendekati fungsi ojaif normal. Hasil uji KhiKuadrat diperoleh nilai Khi-Kuadrat hitung jauh lebih kecil dari Khi-Kuadrat tabel, berarti independensi lokal terpenuhi.

Asumsi invariansi parameter menyatakan bahwa parameter butir tidak tergantung pada parameter siswa dan sebaliknya para- meter siswa tidak tergantung parameter butir. Invariansi pada butir tes dibedakan dalam dua bagian, yaitu: 1) invariansi terhadap estimasi parameter-parameter butir tes, dan 2) invariansi terhadap parameter kemampuan (Hambleton, Swaminathan, \& Rogers, 1999, p.19).

Uji invariansi parameter kemampuan, dilakukan pemilahan butir tes ganjil dan butir tes genap. Kedua kelompok kemampuan dikorelasikan, apabila korelasinya tinggi, maka asumsi invariansi kemampuan terpenuhi (Syarifah, 2007, p.16). Hasil uji invarian paramater menunjukkan bahwa korelasi antara estimasi kemampuan peserta butir ganjil dan kemampuan peserta butir genap sebesar 0,822, sehingga dapat dikatakan bahwa asumsi invarian terpenuhi.

Secara umum, karakteristik butir soal yang telah dikembangkan memiliki tingkat kesukaran (b) dari -2,158 sampai dengan 2,5283; daya beda (a) dari 0,391 sampai dengan 2,317, dan tebakan (c) memiliki nilai minimum sebesar 0 (karena model yang dipilih adalah model logistik 2 parameter) dan nilai informasi butir berkisar antara 0,111 sampai dengan 3,879.

Pemilihan model logistik yang digunakan untuk analisis butir tes terlebih dahulu dilakukan uji fit butir tes terhadap model. Penelitian ini dipilih model logistik 2 parameter dengan pertimbangan bahwa setelah diuji fit model ternyata model logistik 2 parameter lebih banyak butir tes yang fit dibandingkan dengan model logistik lainnya.

Fungsi informasi uji tes ditentukan oleh fungsi informasi tiap-tiap butir tes yang membentuk uji tes tersebut. Berdasarkan respons peserta terhadap uji tes tertentu dapat dihitung informasi maksimal yang dapat diberikan oleh uji tes tersebut dengan memasukkan nilai rentang $\theta$ tertentu (misalnya dari -2 sampai +2), daya beda tiap butir tes, dan tingkat kesukaran tiap butir tes. Uji tes yang dikembangkan memberikan informasi maksimal (tertinggi) pada kemampuan peserta $\theta=0$ dengan nilai informasi sebesar 31,636 . 
Secara keseluruhan, uji tes memberikan informasi yang tinggi pada rentangan kemampuan peserta antara -1 dan +1 , sedangkan di luar kemampuan tersebut akan memberikan informasi yang rendah. Hal ini menunjukkan bahwa uji tes yang dikembangkan secara umum sangat cocok bagi peserta dengan kemampuan sedang. Dengan kata lain uji tes yang dikembangkan dapat digunakan untuk melakukan diagnosis kesulitan belajar.

Uji kelayakan dan efektivitas TDKBMatSD untuk mendiagnosis kesulitan siswa terhadap indikator yang diujikan, dilakukan dengan teknik uji beda antara dua rerata (Borg \& Gall, 1983, pp.543-545). Rerata skor siswa yang berasal dari sekolah berkategori tinggi (dalam hal ini sebagai kriterianya adalah sebagai SD favorit) dan rerata skor siswa yang berasal dari sekolah berkategori sedang (dalam hal ini sebagai kriterianya SD yang kurang favorit) dibandingkan. Pengujian ini dilakukan dengan program SPSS versi 17.0, apabila nilai signifikansinya $<0,05$ berati TDKB-MatSD yang telah dikembangkan dianggap efektif dalam mendiagnosis kesulitan belajar siswa.

Sebagai sampel untuk uji kelayakan dan efektivitas dalam penelitian ini, berdasarkan hasil tes uji yang diperluas, diambi1 2 (dua) SD di Kota Banda Aceh, 2 (dua) SD di Aceh Besar, dan 2 (dua) MIN, masing-masing pasangan tersebut diperbandingkan dengan syarat sekolah seperti tersebut di atas.

Nilai rata-rata siswa SD Negeri Garot Kabupaten Aceh Besar sama dengan 71,32 dengan standar deviasi 15,67 dengan jumlah sampelnya 76 orang, dan nilai rata-rata siswa SD Negeri Lambheu Aceh Besar sama dengan 55,92, standar deviasi 13,69, dengan jumlah sampelnya 54 orang. Hasil analisis menunjukkan bahwa nilai $\mathrm{t}$ hitung sebesar 5,818 dengan signifikansi $<0,0001$ jauh lebih kecil dari nilai $\alpha=0,05$, berarti bahwa ada perbedaan yang signifikan hasil tes yang diperoleh siswa SD favorit bila dibanding dengan siswa SD yang kurang favorit.
Nilai rata-rata siswa SD Negeri 26 Kota Banda Aceh sama dengan 49,57, standar deviasi 17,60 dengan jumlah sampelnya 30 orang, dan nilai rata-rata siswa SD Negeri 9 Kota Banda Aceh sama dengan 40,05, standar deviasi 12,35, dengan jumlah sampelnya 31 orang. Hasil analisis menunjukkan bahwa nilai t hitung sebesar 2,452 dengan signifikansi 0,017 jauh lebih kecil dari nilai $\alpha=0,05$, berati ada perbedaan yang signifikan hasil tes yang diperoleh siswa SD favorit bila dibanding dengan siswa SD yang kurang favorit.

Nilai rata-rata siswa MIN Tungkob Kab. Aceh Besar sama dengan 34,78, standar deviasi 16,42 dengan jumlah sampelnya 133 orang, dan nilai rata-rata siswa MIN Rukoh Kota Banda Aceh sama dengan 32,06, standar deviasi 18,12, dengan jumlah sampelnya 76 orang. Hasil analisis menunjukkan bahwa nilai t hitung sebesar 1,111 dengan signifikansi 0,268 jauh lebih besar dari nilai $\alpha=0,05$. Hal ini menunjukkan bahwa tidak ada perbedaan yang signifikan hasil tes yang diperoleh siswa MIN Tungkob Kab. Aceh Besar hila dibanding dengan siswa MIN Rukoh Kota Banda Aceh, di mana kedua MIN tersebut sama-sama salah satu MIN favorit.

Berdasarkan tiga kelompok sampel yang telah dijelaskan di atas, menunjukkan bahwa TDKB-MatSD yang dikembangkan mampu membedakan secara signifikan kelompok yang favorit dan kelompok nonfavorit. Ini berarti TDKB-MatSD yang dikembangkan telah berfungsi sebagai instrumen untuk mendiagnosis kesulitan belajar siswa SD khususnya materi bilangan.

Software komputer yang dirancang untuk melakukan analisa hasil diagnosis kesulitan belajar matematika adalah software Microsoft Office Excel 2007. Menu utama pada layar pembukanya adalah Data Siswa dan Hasil Tes, Nilai, Profile Siswa, Analisis Semua Jawaban, Analisis Jawaban Benar, Analisis Jawaban Salah, Grafik Ketuntatsan Belajar, dan Analisis Indikator.

Menu Grafik (diadaptasi dari Waskito dan Kumaidi, 2010) berisi informasi secara klasikal tentang grafik ketuntasan belajar 
siswa di kelasnya bila dibandingkan dengan nilai KKM yang ditetapkan. Apabila nilai yang diperoleh siswa lebih besar dari nilai KKM yang ditetapkan, maka grafiknya akan muncul di atas garis KKM, apabila nilai yang diperoleh siswa di bawah nilai KKM, maka grafiknya akan berada di bawah garis KKM.

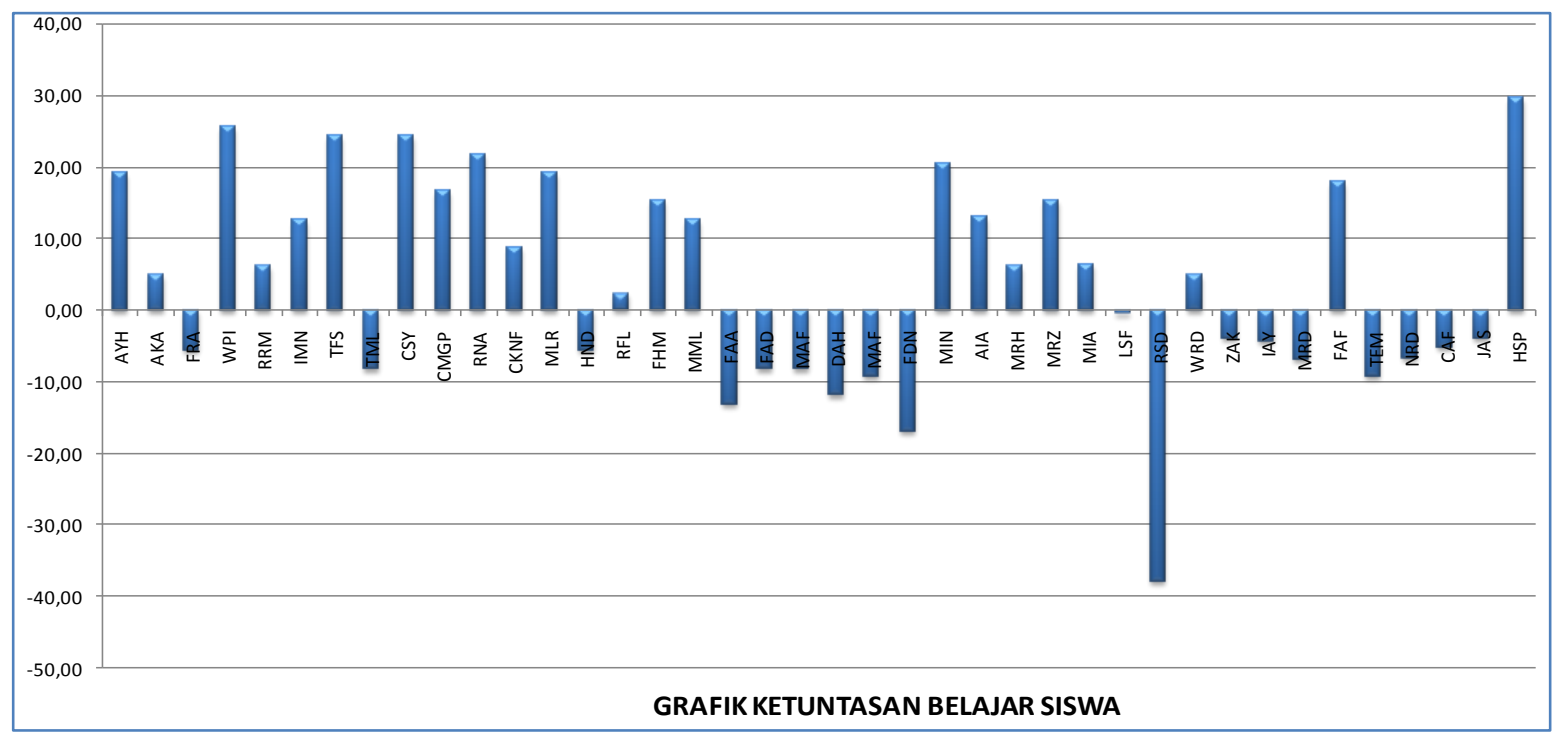

Gambar 1. Grafik Ketuntasan Belajar

Semakin tinggi nilai perolehan di atas KKM maka grafiknya akan semakin tinggi pula. Sebaliknya apabila nilai yang diperoleh siswa jauh di bawah KKM maka grafiknya akan menghunjam ke bawah. Informasi ini sangat berguna bagi guru untuk memperoleh informasi siswa mana saja yang mengalami kesulitan belajar dan siswa mana pula yang tidak mengalami kesulitan belajar. Siswa yang grafiknya di atas garis KKM, terutama siswa-siswa yang grafiknya lebih tinggi dari siswa yang lainnya, dapat dimanfaatkan oleh guru sebagai teman sejawat dalam melakukan remedial terhadap peserta didik yang grafiknya di bawah garis KKM.

Analisis Indikator berisi informasi secara klasikal tentang daftar indikator kemampuan yang diujikan dan nama-nama siswa yang merespons indikator tersebut. Hasil respons tersebut berupa informasi benar (B) atau salah (S) tiap indikator yang diujikan bagi setiap siswa, jumlah siswa yang menjawab dengan benar, jumlah siswa yang belum berhasil menjawab dengan benar, jumlah siswa yang tidak menjawab, persentase jawaban benar, dan ketuntasan secara klasikal terhadap tiap indikator yang diujikan. Hasil print out dari Analisis Indikator yang diujikan sangat berguna bagi guru untuk mendapatkan informasi tentang siswa-siswi mana saja yang menjawab benar dan siswa-siswa mana pula yang belum berhasil menjawab dengan benar indikator yang diujikan. Dengan demikian, guru dapat dengan tepat melakukan remedial bagi siswa yang belum berhasil dan memberikan pengayaan bagi siswa yang sudah berhasil berkenaan dengan indikator yang diujikan.

Hasil analisis komputernya, bukan hanya informasi secara klasikal, tetapi juga individual berupa Profile Hasil Diagnostik secara umum (Gambar 2), hasil analisis semua butir yang direspons oleh siswa ditampilkan dalam menu Analisis Semua Jawaban, analisis jawaban untuk butir yang dijawab benar dalam menu Analisis Jawaban Benar, analisis jawaban untuk butir yang dijawab salah dalam menu Analisis Jawaban Salah. 


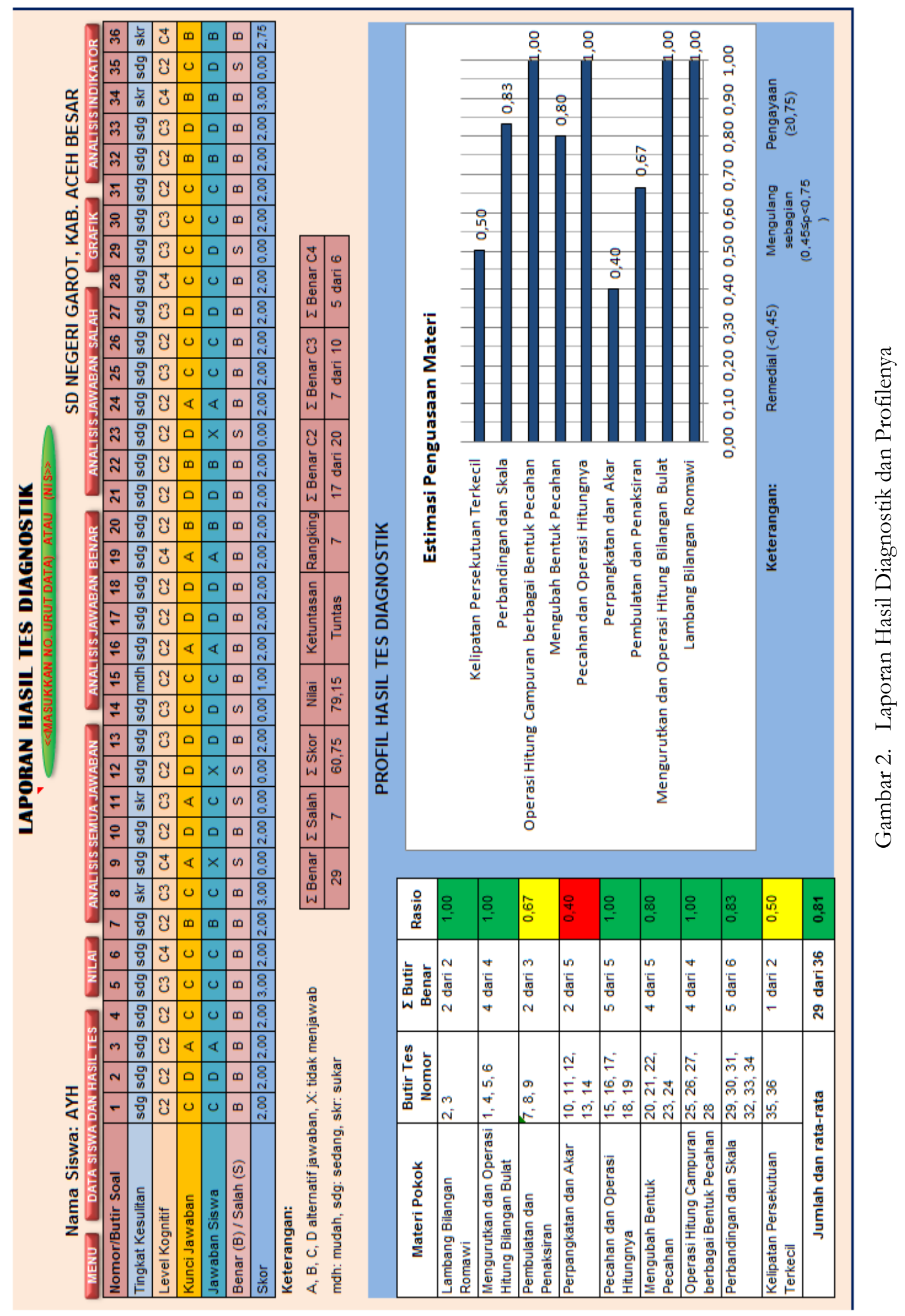


Laporan hasil diagnostik secara umum dalam bentuk Profile Hasil Diagnostik diadaptasi dari model lassporan hasil diagnostik yang dikembangkan oleh Department of Mathematics, Keele University, yang dikembangkan oleh Rupp, Templin, \& Henson (2010, p.31). Perpaduan dari kedua bentuk laporan tersebut dan beberapa informasi penting lainnya, termasuk laporan hasil diagnostik yang dikembangkan berisi informasi secara individual tentang semua jawaban yang direspons terhadap butir soal. Semua laporan tersebut dapat digolongkan ke dalam penilaian autentik, dimana menampilkan sesuai dengan kompetensi yang sebenarnya dimiliki oleh masing-masing siswa menurut kompetensi dasar yang telah dipelajarinya.

Tanggapan guru terhadap produk software komputer untuk menganalisis hasil TDKB-MatSD, diperoleh informasi bahwa software yang dikembangkan layak dan dapat digunakan untuk keperluan mendiagnosis kesulitan belajar matematika jenjang SD/MI dengan rata-rata 3,689 (dalam skala 1 - 4). Hasil prin-outnya dapat dipahami dan berguna sebagai informasi untuk perbaikan pembelajaran.

\section{Simpulan}

Berdasarkan hasil penelitian dan pembabasan yang telah dikemukakan, maka kesimpulan temuan penelitian ini sebagai berikut.

Pengembangan tes diagnostik kesulitan belajar matematika jenjang $\mathrm{SD} / \mathrm{MI}$ (TDKB-MatSD) ini menggunakan model Research \& Development. Tahap penelitian meliputi studi pendahuluan, studi literatur dan hasil-hasil penelitian, analisis masalah, merumuskan learning continuum, merumuskan peta konsep, menyusun tes berbentuk essay, polarisasi jawaban siswa, dan menyusun tes berbentuk pilihan ganda. Tahap pengembangan meliputi validasi pakar atau praktisi dalam bentuk focus group discussion, uji pendahuluan dan keterbacaan, uji coba terbatas, dan uji yang diperluas sehingga diperoleh model yang fit secara teoretis dan empiris.
Butir tes yang dikembangkan cocok digunakan untuk diagnosis kesulitan belajar matematika materi bilangan kelas VI SD/ MI. Hasil analisis dengan program ITEMAN diperoleh informasi bahwa kisaran tingkat kesukaran butir antara 0,192 sampai dengan 0,731 , kisaran daya beda butir tes 0,221 sampai dengan 0,644 , indeks reliabilitas tes 0,889 , dan rata-rata daya beda soal 0,579 , sedangkan hasil analisis dengan program $\mathrm{R}$ diperoleh indeks daya beda butir tes berkisar antara 0,391 sampai dengan 2,317, indeks kesukaran butir tes berkisar antara -2,158 sampai dengan 2,528, kecocokan uji tes dengan kemampuan peserta $\theta$ berkisar antara -2,00 sampai dengan 2,60, dan fungsi informasi tes berkisar antara 0,111 sampai dengan 3,879 .

Fungsi informasi uji tes secara keseluruhan memberikan informasi tertinggi pada kemampuan peserta $\theta$ sama dengan 0,00 sebesar 31,636. Berarti butir tes yang dikembangkan cocok untuk kemampuan rata-rata peserta, dan sangat cocok digunakan sebagai tes diagnostik.

TDKB-MatSD yang dikembangkan mampu membedakan secara signifikan kelompok yang favorit dan kelompok nonfavorit, hal ini menunjukkan bahwa butir tes yang dikembangkan berfungsi sebagai instrumen untuk mendiagnosis kesulitan belajar siswa SD khususnya materi bilangan.

Laporan hasil analisis tes diagnostik yang dimunculkan bermanfaat bagi guru untuk merencanakan dan melaksanakan perbaikan pembelajaran matematika $\mathrm{SD} / \mathrm{MI}$ khususnya materi bilangan baik secara individual maupun klasikal dalam bentuk remedial teaching.

\section{Daftar Pustaka}

Borg, W. R., \& Gall, M. D. (1983). Educational research: An introduction. London: Longman, Inc.

Fauzan. (2010). Pengembangan tes diagnostik kesulitan belajar matematika di SMA. Disertasi. Yogyakarta: PPs UNY.

Hambleton, R.K., Swaminathan, H., \& Rogers, H.J. (1991). Fundamental of 
item response theory. Newbury Park: SAGE Publications, Inc.

Kumaidi. (2005). Profil siswa dan kelas untuk bantuan peningkatan pembelajaran. Makalah disampaikan dalam Seminar Nasional Hasil Penelitian tentang Evaluasi Hasil Belajar serta Pengelolaannya di PPs UNY.

Naga, D. S. (1992). Pengantar teori sekor pada pengukuran pendidikan. Jakarta: Gunadarma.

Puspendik, (2010). Survei internasional TIMSS. Diakses dari http://litbangkemdiknas. net/detail.php?id=214, tanggal: 13 Oktober 2011.

Rupp, A. A., Templin, J., \& Henson, R. A. (2010). Diagnostic measuremnet: theory, methods, and applications. New York: The Guilford Press.

Sheehan, K. M. (1997). A tree-based approach to proficiency scaling and diagnostic assessment. Journal of educational measurement. Volume 34, Issues 4, pages 333-352, December 1997.

Sriati, Arti. (1994). Kesulitan belajar matematika siswa SMA: pengkajian diag- nostik. Jurnal kependidikan, Nomor 2, Tahun XXIV. Yogyakarta: UNY

Subarinah, Sri. (2006). Pembelajaran matematika sekolah dasar. Jakarta: Depdiknas.

Suwarsono, St. (1987). Trait-treatment interaction dalam pendidikan matematika. Yogyakarta: IKIP Sanata Dharma Yogyakarta.

Syarifah. (2007). Persyaratan analisis instrumen sebagai pra-syarat ketepatanhasil analisis dalam penelitian pendidikan. Jurnal penelitian MIPA. Vol. 1 No. 1, Desember 2007.

Thorndike, R. L., \& Hagen, E. P. (1972). Measurement and evaluation in psychology and education. New York: John Willey \& Sonc.

Waskito \& Kumaidi. (2010). Asesmen untuke memantau kualitas pendidikan. Pengembangan model analisis prestasi belajar untuk mengidentifikasi kesulitan belajar peserta didik. Jakarta: UIN Syarif Hidayatullah Jakarta.

Wijaya, Ariyadi. (2012). Pendidikan matematika realistik suatu alternatif pendekatan pembelajaran matematik. Yogyakarta: Graha Ilmu. 